\title{
A Room of One's Own in Suzhou: Analyzing the Dissemination of Woolf's Feminism in China
}

\author{
Yaxin $\mathrm{Liu}^{1, *}$ \\ ${ }^{1}$ CMII University College London, London, UK WC1E $6 B T$ \\ ${ }^{*}$ Corresponding author. E-mail :liuleahmail@163.com
}

\begin{abstract}
How do the Chinese promoters of the women's liberation movement in modern China identify females in the face of the discourse of other feminist scholars? Do they completely accept or make a clever transition? As the first person to spread Woolf's feminist ideas, Xu Zhimo recognizes the important role that women play in cultural production, but subtly avoids Woolf's idea of female financial independence and gender equality. He ignores the fact that women's "other" status and male-dominated discourse aggravate the plight of women. Behind it lies the problem of class limitation and unequal relationship between gender power. This article is based on Virginia Woolf's A room of one's own and Xu Zhimo's About women as comparative texts, analyzing the gender relations embodied in the absorption and transition of modern China. It provides a particular view for exploring the development of female consciousness in Modern China.
\end{abstract}

Keywords: Feminism, Gender relations, Modern China, Virginia Woolf, Xu Zhimo

\section{INTRODUCTION}

A Room of One's Own [1] is based on two lectures delivered by British female writer Woolf for the students at Women's College. In October 1928, Woolf came to Cambridge University and gave speeches on women and fiction at Newnham College and Girton College, analyzing women's writing facing limited educational opportunities, loss of economic rights and the dilemma of unequal division of labour, paying attention to women's equality in social status and the right to speak independently. Woolf mentioned at the beginning "a woman must have money and a room of her own if she is to write fiction; and that, as you will see, leaves the great problem of the true nature of woman and the true nature of fiction unsolved." Money and the space of her own are the necessary conditions for Woolf to consider women's participation in writing. It shows that the economic and spatial free control is an important means for women to get rid of their subordinate status and achieve individual independence. In December of the same year, Xu Zhimo was invited to Jiangsu Women's College to give a speech on About Women[2]. Xu Zhimo also mentioned in his speech that he saw an article written by a woman British novelist. She said that women who want to engage in writing must have at least two conditions: one is that she must have a room of her own, which she has the freedom to lock or lock at any time; the other is that she must have profit about five hundred pounds a year. The "English novelist" that $\mathrm{Xu}$ Zhimo mentions is Woolf. He passed Woolf's ideas on the promotion of women's social status to modern Chinese intellectuals with his own understanding. This paper compares Xu Zhimo's speech in Suzhou Women's College with Woolf's speech in Cambridge University and analyzes $\mathrm{Xu}$ Zhimo's absorption and variation of Woolf's feminist thoughts. Through the analysis of Xu Zhimo's definition of "new women", it can be seen that Xu Zhimo advocates women's equal right to education and encourages women to accept knowledge and create. At the same time, his views also included the avoidance of women's economic freedom and the neglect of men's privileges. Xu Zhimo was the first person to spread Woolf's feminist thought in modern China. The study of his dissemination of Woolf's feminist thought provides another perspective for further understanding the development of Chinese feminism, and plays an important role in enriching the origin, dissemination and variation of modern Chinese "female consciousness".

\section{LITERATURE REVIEW}

According to the argument in The British Lily in the 20th Century Literary Circles-Virginia Woolf in China [3], Xu Zhimo was the first scholar to spread Woolf's 
feminism in modern China. And Woolf's two speeches were also introduced by $\mathrm{Xu}$ Zhimo and became the first work of Woolf feminism spread in modern China. After it was published in 1929, "A Room of One's Own" attracted many scholars' attention. In the past decade, many scholars borrowed from Woolf's feminist ideas in this work and used it as a method of analyzing texts and social phenomena. For example, in Voices from a Room of One's Own: Examples from Contemporary Chinese Women's Poetry [4], the author adopted ideas from Virginia Woolf's A Room of One's Own to explore how women poets find a private space to embody "liberated" selves; many scholars follow Woolf's text creation methods. For example, in Towards a Transnational Turn in Narrative Theory: Literary Narratives, Traveling Tropes, and the Case of Virginia Woolf and the Tagores [5], the author proposed the concept of "the implied story" embedded in tropes that travel transnationally in $A$ Room of One's Own. Some scholars have also paid attention to the dissemination of Woolf's feminist ideology in China, and linked Woolf and Xu Zhimo. For example, the spiritual fit and cultural dialogue [6] connects Bloomsbury Set with modern Chinese literary groups to exchange their ideas. Among them, the analysis of comparative literature variation-the variation of Woolf's "A Room of One's Own" in China [7] focuses on the close connection between the two works. Among them, the variation of comparative literature -- the variation analysis of Woolf's A Room of One's Own in China focuses on the close connection between the two works. On the basis of the Variation Study of Comparative Literature, the author further discusses the similarities and differences between Woolf and $\mathrm{Xu}$ Zhimo. It affirms the sensitivity of Chinese scholars to feminist trends around the world. At the same time, it is pointed out that the generalization of female's dilemma proposed by Woolf is limited to the elite class and masculinity.

\section{WOMEN WHO HAVE BEEN "OTHER"}

In her speeches, Woolf expounded a lot about the women's identity and contents of female writing. The first is the creation of women's identity. The originator of female writing is female. Woolf mentioned in her speech what she thought was strange: Some of the most inspired words, some of the most profound thoughts in literature fall from her lips; in real life she could hardly read, could scarcely spell, and was the property of her husband. In Woolf's view, if women want to embark on the road of writing, in addition to having the ability to read and write, they must also get rid of their role as the "private property" of the family. She used the example that Jane Austen had no separate room and could only write quietly and guiltily in a public room. She also assumed that if Shakespeare had a talented sister, it would still not be possible for her to write plays like Shakespeare. These two examples criticized the unequal social status and family division of labour that men used to set at the beginning. Under the restriction of male rights, women are trapped in the kitchen and housework, and have no time or space to finish writing. She also pointed out that, whether in the family or in society, women are often weakened by men, and they exist to set off men. In her speech, she used "Women have served as looking glasses" to describe, pointing out that the disadvantaged position of women under control was the result of being male others. In her view, women do not have the right to speak independently. They are the "other" who were observed by men. Moreover, Females are a "mirror" for men to complete the construction of their identity subject. Woolf cleverly used "anger" to criticize the patriarchal oppression and dominance of women because of her lack of self-confidence in her own status, using female subjective consciousness and lack of discourse power to bring out the strength of men's status to affirm self-worth.

In Xu's speech, he asked women to take the initiative to enrich themselves. He encouraged them to become thoughtful and talented female writers like Woolf. His remarks have a progressive effect on promoting women's equal rights in education and improving their knowledge level. Xu Zhimo introduced the plight of women described by Woolf in this work as facts to young Chinese women, but he cleverly filtered out Woolf's purpose for citing these examples. Instead, self-discipline and self-motivation that are more in line with traditional Chinese values are replaced, and women who were educated at that time are encouraged to take on the important tasks of the times [7]. While focusing on encouraging young women to increase their learning, he avoided the fact that women were severely weakened under the oppression of patriarchy. Xu Zhimo put forward his own views on the writing process of Jane Austen, thinking that even if Austen were under the premise of "no room that can open and close" and "no fixed income every year", she can still create good works. He believed that it was "their outstanding genius, vigorous enthusiasm and surpassing imagination" that forced them to write. He tries to lead women to focus their struggles on themselves -- women's success is due to their talent and hard work, and women's failure is not due to external factors that marginalize them. He tried to steer the women's liberation movement in the direction of outdated ideas and personal awakening. Thus it is pointed out that women's predicament is the result of their own factors. Women's "other" identity is an important source for men to construct their own status. While avoiding the dominance of male power, $\mathrm{Xu}$ Zhimo potentially places women and men in a binary opposition structure. On the one hand, he points out that men have made more great achievements than women, and on the other hand, he points out that men are the driving force behind women's status and progress. For example, he pointed out that "The great literati of the Qing Dynasty, Wang Yuyang, Yuan Zicai, Bi Qiufan, and Chen Bicheng, were the 
greatest heroes in promoting women's literature." All the promoters of women's literature he lists are men, which proves from the side that "women cannot completely blame men's intentional oppression". When Xu Zhimo advocated male "self-beauty", the status of female "other" was further deepened invisibly. In fact, the argument that women do not improve themselves is used to highlight men's superior status, to further consolidate women's subordination to men. This is precisely what Woolf fought against for the status of women.

\section{GENDER POLITICS BEHIND LIMITATIONS}

In a speech in October 1928, Woolf repeatedly questioned the creative content of female writers. She pointed out that female writers represented by Jane Austen started to create novels rather than poems, and sharply emphasized that "women cannot write Shakespeare drama". The reason is also reflected in the speech. She mentioned that when she tried to cross the grass, she was stopped by the deacon of the parish because she was a female. She also mentioned that if Mary Seton's mother was in business and had her own assets, they could sit comfortably and discuss natural sciences. Woolf tried to use these cases to inform people that although women have the right to education, their access to knowledge is still limited. In the family, men control women's economic rights and deprive them of their ability to live independently; in society, men control the way to gain knowledge and exclude women to consolidate their voice. Woolf revealed the gender politics hidden behind the limitations of women's writing content, and emphasized the use of intellectual freedom and economic freedom as weapons to resist the rule of patriarchy and eliminate women's subordinate status.

Perhaps inspired by Woolf, Xu Zhimo's speech also has remarks about women's writing content. He does not approve of the content of ancient women's works and thinks that they are just "expressing their personal experiences and occasional emotions." He cleverly avoided the reasons for the single and limited content of ancient women's creations. Instead, he put forward higher requirements for modern "new women" considering this limitation: The ambitions of new women should be shared with men and continue to produce the entire cultural industry of mankind.

From the above analysis, it can be seen that xu Zhimo deliberately avoided words that were not conducive to men and blurred the target of the struggle, hiding the oppression of patriarchy on women behind the struggle when advocating feminist speech. In his attitude towards the content created by women, $\mathrm{Xu}$ again covers up the factors that force women to be in a subordinate position. He proposed the idea that women should cooperate with men. He goes so far as to point out that, except in unreasonable and superstitious social organizations, a woman is a wife, a mother, and nothing else. She can take care of two or more qualifications at the same time, just as a man's paternity cannot harm his character. He created a perfect image of "elite women" for modern women: while completing the division of roles of women in the family, he also perfectly considered the division of roles of women in society. This, of course, was his personal project, which included his expectation of the "union of the sexes" in the course of the modern revolution. In his conception, the process of promoting social reform needs to absorb the power of women, so as to improve the revolutionary struggle ability of the bourgeoisie. Such a conception is obviously motivated by the selfishness of the male bourgeois revolutionaries. On the one hand, "new women" is defined in terms of male-dominated discourse. In Xu's view, "new women" are a social force to be harnessed." The new woman "cannot emerge as a social division with men; On the contrary, the "new women" should be the assistants of elite men, the supporting forces against feudal forces. This certainly played a positive role in the historical process of opposing feudalism. However, from the perspective of female equality and individual liberation, this is undoubtedly to further bind women to men. Because the "cooperation" between new women and elite men is not established on the basis of equality, elite men still dominate. On the other hand, male power forces women to bear the double pressure of family division of labour and social division of labour. The definition of "new women" is used to cover up their requirements for elite women, thus confining women in the unreasonable division of labour in the family, which virtually exacerbates the plight of women.

\section{CONCLUSION}

Woolf even raised questions in her speech: Why are women, judging from this catalogue, so much more interesting to men than men are to women? Reviewing the spread of feminism in modern China in the early period of the May 4th Movement, it is not difficult to find that, as a women's liberation movement, the voice of feminism was mostly bourgeois men. It is undeniable that this early feminist movement spread by bourgeois male intellectuals played an important role in promoting the awakening of women's individual consciousness and constructing women's equal social status. However, the limitation of male discourse position and class is not conducive to the emancipation of women from the "other" status, and also increases the difficulty for women to get rid of the subordinate status.

\section{ACKNOWLEDGMENT}

As the first article that contributes to the journal as the only author, the process of preparation, writing and revision is a good opportunity to learn academic skills. It makes me enjoy more preciseness and truth-seeking in 
the academic road. Firstly, thanks to my tutors for the correction guidance. Their recommendations inspire me a lot. Secondly, thank my parents to support my academic efforts. Their encouragements keep me at my best. And finally, thanks for my belief that I will always have the courage to keep achieving my dream.

\section{REFERENCES}

[1] Virginia, W. (1989). A Room of one's own. Mariner Books.

[2] Zhimo, X. (2018). Collection of Proses. CreateSpace Independent Publishing Platform.

[3] Lixin, Y. (2009). British Lily in the 20th Century Virginia Woolf in China. People's Press, pp.30-34.

[4] Lisa Lai-Ming, W. (2006). "Voices from a Room of One's Own: Examples from Contemporary Chinese Women's Poetry.” Modern China, 32(3), 385-408. JSTOR, www.jstor.org/stable/20062644.

[5] Susan Stanford, F. (2011). Towards a Transnational Turn in Narrative Theory: Literary Narratives, Traveling Tropes, and the Case of Virginia Woolf and the Tagores. Narrative, The Ohio State University Press, 19 (1). 132,10.1353/nar.2011.0003.

[6] Xiaoxia, Y. (2012). Spiritual fit and cultural dialogue. Fudan University, PhD dissertation.

[7] Shunqing, C., Xuerui, L. (2018). Analysis of Comparative Literary Variations - The Variations of Woolf's One Room in China. Journal of Shanghai Normal University (Philosophy and Social Sciences Edition), 47(04),5-12. doi:10.13852/J.CNKI.JSHNU.2018.04.001. 